\title{
East central European urbanization: a political economy of the world-system perspective
}

\author{
by Michael D. Kennedy and David A. Smith*
}

What is the nature of urbanization in eastern Europe, historically and in the present day? Has it followed a single path related to other macrostructural changes? Is the contemporary pattern of urbanization the result of the region's 'noncapitalist' political economy? Is it a function of these societies' 'level of development'? What effect has the region's role in the world-system had on its urban trajectory?

In an attempt to provide satisfactory answers to these questions, we develop a synthetic perspective on urbanization and social change which emerges from the confluence of two streams of social scientific inquiry: the 'new urban sociology' (Walton, 1979; 1981) and the dependency/world-system approach to comparative development. Others have brought together these traditions in order to examine urban patterns and processes in light of regional roles in the world system (Walton, 1982; Chase-Dunn, 1984; Timberlake, 1985). We extend this effort in several ways.

Our focus on east central European urbanization from the long sixteenth century through to the second half of this one is an important departure for theoretical reasons from the perspective's main focus on dependent urbanization in the third world. It enables us to sharpen the concepts of semi-periphery and periphery. In particular, it shows the importance of transcending economistic biases of some world-system formulations by theorizing the role of the state in guiding urban outcomes.

We begin with a review of literature on the semi-periphery and periphery, urbanization and the state. We then turn to an examination of contemporary urban patterns in Hungary, Poland and Czechoslovakia. Because these patterns

*Coauthors have contributed equally and are listed in alphabetical order. We thank Lianne Oakes, Cindy Buckley, Christopher Chase-Dunn, Robert Denemark, Bohdan Jalowiecki, George Kish, John Liu, Linda Miller, Dorothy Solinger, and two anonymous reviewers for comments on earlier drafts. Some of the data referred to in this text were collected and analysed while Michael Kennedy was on a grant from the Joint Committee on Eastern Europe of the American Council of Learned Societies and Social Science Research Council. Versions of this paper were presented at the Southern Sociological Society annual meeting in 1987 and the University of California, Irvine faculty seminar on 'The State'. 
have their roots in the region's past, the bulk of the paper employs an international political economy perspective to explain the historical trajectory of east central European city growth. Our review of postrevolutionary urban policies in these countries finds that they reinforce east central Europe's semi-peripheral historical legacy. In the conclusion we return to the questions posed at the outset, reflect on the adequacy of our theoretical approach applied to east central Europe, and discuss the lessons these empirical cases provide for further theorizing about urbanization and social change.

\section{Dependent urbanization in the world economy}

The concept of the 'dependent city' or 'peripheral urbanization' is presaged in Frank's description of world capitalist exploitation as a 'metropolis-satellite structure' (1969: 6-9). Castells (1977) systematically related dependency and urbanization, arguing that, like other processes of macrostructural change, urban growth in underdeveloped parts of the globe is tied to capitalist penetration and expansion. These initial formulations have been followed by a number of empirical studies applying the logic of the international political economy approach to comparative research on cities and urban systems (Walton, 1977; Slater, 1978; Roberts, 1978; Friedmann and Wolff, 1982; Timberlake, 1985; Meyer, 1986; London and Smith, 1988). Timberlake succinctly summarizes the main premise of this approach:

Urbanization must be studied holistically - part of the logic of a larger process of socioeconomic development that encompasses it, and that entails systematic unevenness across regions of the world. The dependence relation is an important theoretical concept used to pry into the ways in which the processes embodied in the world system produce various manifestations of this unevenness, including divergent patterns of urbanization (1985: 10).

There are three types of 'unevenness' which can be distinguished (Gugler and Flanagan, 1977: 273). First, demographic and economic imbalances occur between the urban and rural sectors, represented in the concepts of 'urban bias' and 'overurbanization'. Secondly, skewed patterns of population distribution are characterized by rapid concentrations of people and resources in the largest towns, leading to debates about 'optimal city size' and 'urban primacy'. Thirdly, great material disparities within cities are reflected in 'dualistic' patterns of housing, consumption, and access to political participation, generating a spinoff literature on housing, slums, squatter settlements, urban poverty and the 'informal sector'.

Social scientists have applied the concept of dependent urbanization to various regions in the third world. Comparative casestudies and crossnational quantitative research have linked some or all of the dimensions of 'uneven urbanization' to the subordinate roles that Latin American, African, and Asian societies have 
played in phases of world economic expansion. Statistical studies indicate that overurbanization is related to peripheral status (Kentor, 1981; Timberlake and Kentor, 1983; Bradshaw, 1985; London and Smith, 1988). Historical analyses show how differential patterns of incorporation into the world system help to explain contemporary variations in lead-city primacy (Nemeth and Smith, 1985a; Smith, 1985; Saueressig-Schreuder, 1986).

If a region's role in the international system is useful for explaining third-world urbanization, it seems logical to assume that the global political economy might also influence city growth patterns elsewhere. A number of recent studies suggests that urbanization in the advanced core needs to be understood in the context of the international division of labour (Friedmann and Wolff, 1982; Feagin and Smith, 1987). But eastern Europe presents a set of problems for this approach.

Dependency/world-system writers treat noncapitalist societies with some ambiguity. Although prerevolutionary patterns of urbanization might be understood in a context of peripheralization, how are the declared 'socialist' nations of the twentieth century to be treated? Eastern European societies, whatever their historical status, seem to be at an intermediate level in the global system. Have they achieved mobility through processes analogous to those found in other cases of semi-peripheralization? Is socialist transformation a means of dependent development? The role of states and the relationship between them is obviously important in these societies for understanding urbanization and other social change. In what follows we suggest refinements of the international political economy approach which can clarify these issues.

\section{Beyond core and periphery}

Peter Evans (1979a) suggests that the promise of world-system analysis lay in the elaboration of its seminal concepts, in particular, of the semiperiphery and of the possibility of state-directed dependent development. Wallerstein locates the semiperiphery 'between the core and periphery on a series of dimensions' and argues that this stratum comprises a 'necessary structural element of the world-economy' (1974: 349). This is a relational concept which can be measured according to a nation's position in trade networks, commodity chains, power structures, etc. using social network analysis (Snyder and Kick, 1979; Nemeth and Smith, 1985b; Smith and White, 1988). But because of its exacting data requirements, this type of analysis is not useful for measuring world-system status in most historical cases. It is therefore necessary to identify attributional characteristics of the semiperiphery.

The semi-periphery differs politically and economically from either the core or the periphery. The internal productive activities of semi-peripheral areas are a mixture of 'corelike' industrial production and labour-intensive extractive 
'peripherylike' production (Chase-Dunn, 1978; 1988). ${ }^{1}$ Development remains 'dependent' under these conditions because it is constrained by an international economy dominated in the leading sectors by the superior technological, financial, and commercial resources of the core. These mixed economic functions of semi-peripheral nations change the nature of the dominant classes and enable state policies to influence more directly local capital accumulation. Wallerstein (1985: 35) argues that, 'semiperipherality is important because it points to a concentration of state-oriented political activity by major internal (and external) actors'. Although there is considerable variance in ideology, from rightist to socialist, semi-peripheral countries, '.. tend to employ more state-directed and state-mobilizing development policies than do core countries' (Chase-Dunn and Rubinson, 1977: 472).

This idea of dependent development moves the state to a central place in worldsystem analysis. Peter Evans' (1979b) account of Brazil's movement into the semiperiphery highlights the role that the state can play as a mediator of continuing international dependence and as a key player in economic planning, co-ordination and capital accumulation. Actors within the state form a shifting and somewhat unstable 'triple alliance' with local and foreign capital to promote economic growth. Far from being 'epiphenomenal', the existence of a stronger, more interventionist state is the driving force in the rapid (if still internationally dependent) industrialization of Brazil.

The state is not just relevant to Brazil. Evans argues that the developmentalist state of the Brazilian model is a key element separating upwardly mobile thirdworld nations from those which remain peripheral (see also Caporaso, 1981). Cumings (1984) argues that the 'bureaucratic authoritarian industrializing regimes' of Taiwan and South Korea enabled their economies' ascent into the semi-periphery. The concept of semi-peripheral dependent development has even been considered, and hotly contested, for its relevance to postrevolutionary Soviet and eastern European societies (Chase-Dunn, 1982; Clark and Bahry, 1983; Luke, 1984; 1985; Arato, 1985; Zaslavsky, 1984-85; 1985). The state has moved therefore to the very centre of international political economy (Evans, Reuschemeyer and Skocpol, 1985; Evans and Stephens, 1988).

What are the implications of this notion of semi-peripheral dependent development for urbanization? Until recently, most research has focused on 'dependent urbanization', making no distinction between city growth in the

\footnotetext{
${ }^{1}$ As Arrighi and Drangel (1986) point out, the precise nature of activities and products that are either 'corelike' or 'peripherylike' is historically bounded and related to current technology and product cycles (Schumpeter, 1964; see Cumings, 1984, for a description of contemporary northeast Asia). Core activities are highly profitable and embody the latest technological innovation (Arrighi and Drangel, 1986). In the eighteenth century, shipbuilding might fit (ChaseDunn, 1978); in the twentieth century, automobiles or computers (Cumings, 1984). At any rate, semiperipheral countries, with a developing mix of such economic activities, are more likely to attract foreign and local investment in manufacturing industries and develop or import new productive technologies than is the periphery (where agriculture and mining remain predominant).
} 
periphery and the semi-periphery. Statistical analysis now finds that the contemporary semi-periphery generally has lower rates of urban primacy than the periphery (Fiala and Kamens, 1986). Historical comparisons show that extreme urban unevenness and inequality may be reduced even further in upwardly mobile, semi-peripheral societies (Smith and Nemeth, 1988). For example, in South Korea the logic of export-oriented industrialization has favored a relatively decentralized spatial distribution of population and production (Nemeth and Smith, 1985). But the state is the distinctive and formative actor shaping urbanization and development in the semi-periphery:

In all the cases of 'semiperipheral urbanization', government policies toward tariff and trade restrictions, infrastructural developments (especially regarding transportation/ communication systems), and the location of key industries, have led to more balanced urban and regional economic and demographic growth (Nemeth and Smith, forthcoming:30).

Because city growth and urban structure are the outcomes of political-economic struggles and explicit and implicit policymaking by powerful people (London, 1979), and because the semi-periphery of the world-system is characterized by state apparatuses which are particularly efficacious and prone to intervention, one should expect a distinctive character of city growth in the semi-periphery.

\section{III 'Socialist' urbanization in the world economy?}

Attempts to explain social change in eastern Europe usually begin with an understanding of the nature of these societies, even though this is a most controversial starting point. They have been characterized as socialist, protosocialist, state-capitalist, in transition between capitalism and socialism and an entirely new mode of production. But even for those who label these societies as a kind of state capitalism, eastern Europe differs in basic ways from western capitalist societies. There is no private ownership of the major means of production: the state owns and directs all large industries. There is no real competition in production among those who control capital, and enterprise managers face fundamentally different kinds of budget constraints (Kornai, 1980).

There is also considerable state control over space in eastern Europe. If land is not owned by the state, there are stringent limitations, especially in large cities, over how it can be bought or sold. Means of collective consumption like electricity and public transportation also lose their commodity status. Their production is not designed to be bought and sold for a profit by producers. Ostensibly they are produced with the consumption of the user in mind. The ideological principles behind the allocation of housing in actual socialism illustrate the systemic difference with capitalism: '1) housing should be a universal provision, not a market commodity; and 2) its production and distribution should not be a means of unearned income' (Szelenyi, 1983: 28). Such principles of socialist urbanism may not be realized in practice and recent reforms even cast doubt as to whether 
these remain the system's official guidelines. Nevertheless, actual socialism ought to produce a different pattern of urbanization than capitalism, even if it may not realize socialism's promise (for a similar argument about Chinese urbanization see Whyte and Parish, 1984). ${ }^{2}$

While actual socialist societies may not be capitalist, they are nevertheless affected by the operation of the capitalist world-system (Frank, 1977; ChaseDunn, 1982). Although most of the societies of eastern Europe and the USSR are politically and militarily integrated, leading some scholars to call the region 'a virtual Soviet empire' (Chirot, 1986: 283) or a Soviet 'world system' (Zaslavsky, 1984-85), the measure of economic integration among these east European societies is far more limited. Each east European society carries on extensive trade with the USSR, but there is an increasingly comparable level of trade with the capitalist west, especially in Hungary and Poland. ${ }^{3}$ Development in Soviettype societies too has been forced to compete with capitalism on the global level, since socialism has promised not only a more egalitarian form of development, but also a more rational and satisfying one.

Given these relationships between the world capitalist system and actually existing socialism, an important question arises: to what degree do these noncapitalist societies share important characteristics with other societies in the capitalist world-system? Despite their special relationship to the USSR and despite different internal relations of production, do east European societies play a role structurally analogous to other semi-peripheral nations (Chase-Dunn, 1982)? How does this world system status affect urbanization?

A final theoretically relevant characteristic of eastern European countries that cannot be overlooked is that they are industrial societies. Developmentalists argue that essential features of these societies, including patterns of urbanization and development, ought to share more in common with western Europe and North America than with industrializing societies like South Korea or Brazil. From this perspective, strategies of technological development and overall

\footnotetext{
${ }^{2}$ Incorporation into the capitalist world system in the middle of the nineteenth century changed Chinese urbanization patterns. The even distribution of cities in independent China gave way to the growing primacy of those ports which linked China to the capitalist core. These cities were characterized by terrific poverty, crime and other social ills. Communist urban reform challenged the legacy of capitalism by limiting migration to these larger cities, redistributing resources to smaller cities in the interior and creating more equality in general. Indeed, Whyte and Parish (1984:359) consider the primary features of actual socialist political economy ('relative equality, bureaucratic allocation, persistent political campaigns and penetrating organizational system') to be more developed in China than in eastern Europe. As China becomes less isolationist, might its urbanization grow less distinctive?

${ }^{3}$ Poland's imports from advanced capitalist countries increased from $25.8 \%$ in 1970 to $49.3 \%$ of total imports in 1975; the proportion of exports to them was $28.3 \%$ in 1970 and $31.5 \%$ in 1975 . Even after the economic crisis began, in $198128.9 \%$ of Poland's imports came from these countries, and $29.5 \%$ of exports went to them (Rocznik Statystyczny, 1983: 334). In 1981, the capitalist industrial world provided $40.2 \%$ of Hungarian imports, and received $30.2 \%$ of its exports (Kovrig, 1984: 107).
} 
economic growth are the primary factors shaping urbanization (Lenski and Lenski, 1987; Jalowiecki, 1982; Andrusz, 1984).

An adequate understanding of east European urbanization using a political economy of the international system approach needs to address these alternative formulations which stress the mode of production and level of development as key explanada. An investigation of cities in this region is especially suited to assess the unique contribution of this perspective since these societies are industrial, are not capitalist, and occupy an unclearly specified status in the world-system.

An analysis of eastern European urbanization goes beyond the bounds of this paper. Viewing eastern Europe in a monolithic way is common given contemporary geopolitical divisions, but these societies' experiences with city growth and urban development are heterogeneous. In this analysis we focus on three countries of east central Europe with relatively similar experiences: Hungary, Poland and Czechoslovakia. ${ }^{4}$

\section{Contemporary pattern: 'underurbanization' and low inequality}

In the contemporary third world, dependent urbanization is often characterized by extremely rapid city growth, overurbanization, lead-city primacy, and high levels of poverty and inequality in metropolitan areas. Urbanization in eastern Europe has followed an almost diametrically opposed trajectory, contrasting on all three dimensions.

Rather than being overurbanized, underurbanization is more characteristic of eastern Europe in general, and east central Europe in particular. Although Lenin first refers to 'under-urbanization' in prerevolutionary Russia (1956), the concept was reintroduced to describe a pattern of urban population growth lagging behind industrial job creation in east central Europe in the 1960s and early 1970s (Konrad and Szelenyi, 1977; Szelenyi, 1981). ${ }^{5}$

In 1970 just slightly over half of the Polish (52.4\%) and Czechoslovak (52.2\%) populations lived in urban areas (Musil, 1980). This is quite low compared to other societies at comparable levels of development (Musil, 1980). ${ }^{6}$ By 1975,

\footnotetext{
${ }^{4}$ We do not consider East Germany, given its special relationship to the capitalist world-system through West Germany. We also do not consider the Balkans, Romania, Bulgaria, and Yugoslavia, as they have been less industralized in both past and present, historically dominated by the Ottoman Empire rather than Austrian, Prussian or Russian, and comparatively lacking in native bourgeoisie or aristocracy in the prerevolutionary era. Yugoslavia is a special case in itself, given its greater openness to western trade and ruling ideology of self-managing socialism. Albania was excluded for the singularity of its contemporary path of isolated development, and for the accompanying lack of data.

${ }^{5}$ This concept of underurbanization examines the ratio of demographic growth in cities to either participation in the industrial labour force or the rate of national economic growth (and is therefore the precise obverse of commonly employed measures of 'overurbanization' (Kentor, 1981: Timberlake and Kentor, 1983; Bradshaw, 1985)).

'These data depend on administrative definitions of urbanity, however, and therefore do not take into account rural transformation that minimize the distinction between town and country.
} 
Table 1(a) Patterns of urban primacy: recent data for eastern Europe and some comparative cases

\begin{tabular}{|c|c|c|c|c|c|c|}
\hline \multirow[b]{2}{*}{ Country } & \multicolumn{4}{|c|}{ Standard primacy index } & \multirow{2}{*}{$\begin{array}{l}\% \text { Cities } \\
100000+ \\
1970^{*}\end{array}$} & \multirow[b]{2}{*}{ Lead city } \\
\hline & 1950 & 1960 & 1970 & 1975 & & \\
\hline Albania & 0.78 & 1.14 & 1.47 & 2.13 & 8.8 & Tirane \\
\hline Bulgaria & 5.70 & 3.54 & 2.29 & 2.19 & 20.9 & Sophia \\
\hline Czechoslovakia & 3.32 & 3.02 & 2.15 & 1.22 & 15.81 & Prague \\
\hline Hungary & 12.71 & 12.86 & 12.32 & 12.15 & 24.7 & Budapest \\
\hline East Germany & -11.10 & -9.77 & -18.62 & -18.68 & 23.7 & Leipzig \\
\hline Poland & -1.31 & -.39 & -.75 & -1.03 & 30.9 & Warsaw \\
\hline Romania & 5.57 & 5.53 & 3.66 & 4.43 & 27.2 & Bucharest \\
\hline Yugoslavia & -4.07 & -2.21 & -3.45 & -5.57 & 13.6 & Belgrade \\
\hline
\end{tabular}

Table 1(b) 1970 data for some other nations

\begin{tabular}{lrl}
\hline Country & Primacy Index & \%Cities $100000+$ \\
\hline Austria & 9.66 & 34.0 \\
Denmark & 9.63 & 34.8 \\
Finland & 1.33 & 23.7 \\
France & 9.42 & 42.3 \\
W. Germany & 2.28 & 51.7 \\
Japan & 4.17 & 47.2 \\
Norway & 5.68 & 23.5 \\
Spain & -2.76 & 41.0 \\
Sweden & 2.91 & 33.1 \\
UK & 2.39 & 68.3 \\
USA & -10.20 & 62.6 \\
USSR & -1.12 & 31.8 \\
China & -3.45 & 11.3 \\
Mexico & 10.24 & 35.8 \\
Philippines & 14.25 & 16.5 \\
S. Korea & 5.72 & 36.2 \\
Thailand & 17.82 & 9.0 \\
\hline
\end{tabular}

Note: The 'standard primacy index' data come from the unpublished results of work by Christopher Chase-Dunn and his collaborators on a research project entitled, 'World division of labor and the development of city systems', funded by the National Science Foundation (of the USA) in 1979. The measure, explained in detail by Walters (1985), uses the size of the largest city as a starting point and calculates deviations from the rank-size rule. The percentage of the population in cities over 100000 was calculated directly from United Nations data in Patterns of urban and rural development growth (UN, 1980). 
Poland's level of urbanization was even less than that of Finland, despite the fact that Poland's population density is eight times greater (Ostrowski and Valkonen, 1978: 266, 281-83). Furthermore, urban growth rates in eastern European societies are modest - particularly when contrasted with very rapid city growth in the less developed countries of the third world. In recent decades the contradictions of underurbanization are apparently declining, especially as a consequence of changing occupational structures (Murray and Szelenyi, 1984: 100-101). But while the divergent tack of socialist urbanization may abate and underurbanization become a thing of the past, it nevertheless suggests that these even urban outcomes have been realized through a fundamentally different process, and suggests the possibility of alternative future trajectories.

East central European societies also lack the skewed urban size distributions associated with dependent urbanism. Urban primacy is not characteristic. In fact, national city size distributions are quite flat, with the obvious exception of Hungary (Table 1). To some extent this exception proves the rule. The primacy of Budapest is partly a consequence of changes in national boundaries. In the postrevolutionary period, there also have been substantial efforts to contain the growth of the largest cities and encourage the development of medium-sized places (Dziewonski and Jercznski, 1975: 269-71). One of the most notable patterns on Table 1 is the stable or declining levels of lead-city primacy found in all the eastern European nations (except Albania).

Material inequality is much more difficult to gauge than demographic imbalances. Nevertheless, its rise or decline as urbanization and economic growth take place is theoretically crucial. In terms of intraurban inequality there is good reason to believe that eastern European cities have attained a more egalitarian distribution of goods and services than advanced capitalist societies (and, of course, a much more even distribution than in the capitalist third world). The state has made large investments in huge uniform housing estates to meet the needs of urban workers. This comparative equality has not eliminated chronic housing shortages (Misztal and Misztal, 1984). Adequate housing is the good most often reported lacking by Poles (Bialecki and Sikorska, 1982).

Although there are drastic shortages of housing, the homeless population is not like those in the third world or even the advanced capitalist nations. Szelenyi estimates the homeless to be about $10 \%$ of the Hungarian urban population (1983: 51). But these are people who live with parents or in institutions of some kind (like hostels). In eastern Europe, in contrast to the third world or even advanced capitalist cities, very few live on the streets. After nearly a decade of economic crisis, a catholic social worker estimated that in 1986 there were about 2000 people without permanent housing in Warsaw out of a population of over 1.6 million (Diehl, 1986). No one lives in makeshift shanty housing typical of capitalist cities in the third world.

Despite a relative lack of demographic overurbanization, resource allocation and infrastructural investment does show urban bias. Szelenyi (1981) documents how the Hungarian regional management system allocates a disproportionate 
amount of state expenditures in favour of urban areas over their rural hinterlands. For Poland, Weglenski (1983) uses regression analysis to demonstrate that city size is a significant predictor of family incomes, access to education, living space and ownership of household appliances and other basic facilities, even when controlling for social status variables. This concentration of amenities in large cities has led to a pattern of residential segregation the opposite of that found in the west, with professionals living in the central cities and workers residing in the hinterlands (Demko and Fuchs, 1977; Szelenyi, 1983).

Despite evidence of urban bias in resource allocation, these data must be interpreted cautiously. First, urban/rural inequality in these societies is occurring in the context of declining regional inequality, at least through the 1970s (Musil, 1980; Ostrowski and Valkonen, 1978: 291; Szelenyi, 1981; Musil and Rysavy, 1983). Secondly, we need to keep urban/rural inequality in comparative perspective. It is doubtful that the urban bias present in east central European societies would be judged as very extreme by contemporary third-world standards. It is also not obvious that the levels of regional inequality in eastern Europe are much different from those in capitalist societies, although the pattern of distribution of specific goods and services may be quite dissimilar. The east central European urban-rural contrast is more similar to earlier periods in the USA before the relative decline of poverty in rural areas and its concentration in large central cities.

In summary, east central European urbanization has been characterized by some inequalities and especially shortages that are particularly noticeable in housing. These levels of inequality and poverty are, however, less serious than those experienced by rapidly urbanizing third-world societies. The inequalities are also distributed differently from the inequalities which occur in advanced capitalist societies.

Having sketched the overall pattern of urbanization in contemporary east central Europe our task is now to explain it. To do that, we must consider not only the political economy of the present, but also the past, beginning with the contrast between eastern and western Europe at the end of the feudalism and the rise of absolutism.

\section{Historical divergence: cities in eastern and western Europe}

In the 1500 s and early 1600 s Polish towns appeared to be on the same trajectory as their west European counterparts. A number of them had some political autonomy, guilds were becoming increasingly important, trade was flourishing and a substantial merchant class had coalesced. Danzig (Gdansk in Polish), a member of the Hanseatic League, was the most successful city under Polish protection, because it channelled Polish grain to the rest of Europe. It enjoyed considerable autonomy, having its own currency and its own naval fleet, and by 1500 it became the leading city in the League. In 1600, with some 50000 
residents, it was the largest city in Poland, with five times the number of residents in Warsaw and 3 times more than in Krakow or Poznan (Pounds, 1979: 131-32; Davies, 1984: 271-72). Nevertheless, after becoming the capital in 1596, Warsaw also grew considerably. The number of Warsaw residents increased from 4500 in 1500 to over 20000 in the next century. Twentyfive percent of the population of the Polish-Lithuanian Republic (formed in 1569) was urban (Pounds, 1979: 123; Davis, 1984: 305-10). By the middle of the next century, economic and urban prospects in Poland and eastern Europe changed for the worse, especially in comparison to western developments.

Between 1648 and 1660, Poland lost one-quarter of its population. The urban population shrank to $15 \%$ of the Republic by the mid-seventeenth century (Davies, 1984: 318). Of Poland's cities, Warsaw fared the best, but it too lost population, from 18000 in 1655 to 6000 in 1659 (Davies, 1984: 315). Both external and internal features account for this relative and absolute urban decline.

East of the Elbe, serfs were bound more tightly to the land both legally and economically. Even after serfdom was officially abolished in the nineteenth century, the economic dependence of the peasants was so great that there was no mass exodus to towns (Szelenyi, 1981).

Eastern European towns also lost the struggle for political autonomy. Although eastern urban autonomy was similar to that in the west before the $1400 \mathrm{~s}$, in subsequent centuries urban privileges and prerogatives were gradually curtailed by powerful feudal lords and emerging absolutist states (Anderson, 1974; Rev, 1984). As late as the seventeenth and eighteenth centuries, serfs in eastern Europe could be reclaimed by masters no matter how long they had been in the city. These alternative urban histories played a key causal role in differentiating west and east European development, even if urban autonomy was only an important, but not sufficient, condition for the rise of capitalism (Holton, 1986).

The decline of eastern cities was also shaped by international conditions. In the $1500 \mathrm{~s}$, legal changes weakened the native burgher estate in Poland. Trade was taken over by foreigners and agents of the nobility, contributing to the decline of a native bourgeoisie and a weakening of the cities' political position. But the demographic decline of these cities was occasioned by the fall of the grain trade, which happened alongside the plagues and wars which ravaged Poland in the last two-thirds of the 1600 s.

\section{Preindustrial peripheral urbanization}

Wallerstein (1974) claims that 'the new European division of labor' in the 'long sixteenth century' is the beginning of a geographically based hierarchic capitalist world-system. The grain producing regions of eastern Europe were the first periphery (Denemark and Thomas, 1988). As in other monocultural areas in colonial territories, the predominant form of agricultural organization became 'coerced cash-crop labor' (Wallerstein, 1974: 91-95). The result was a pattern of 
core exploitation of the periphery. After many iterations of 'cumulative causation', this led to a continuous amplification of the small economic lead the western core initially enjoyed, and to the underdevelopment of peripheries like eastern Europe.

What effect did this process of early peripheralization have on urban patterns? These towns played different roles from those of towns in the core. In the colonial Americas there were two basic functions: 1) trans-shipment points for the bulk products of monocultural export; and 2) centres of elite consumption (Roberts, 1978; Smith, 1987). While there was little that was generative about these colonial cities, the export economy did necessitate the growth of urban areas at major ports. These cities also became centres of political control and administration centres where local elites maintained residences so they would have access to imported luxury items. In colonial Latin America the result was the growth of primate cities which served as headlinks between the European core and the agrarian hinterland (Roberts, 1978: 38-44).

The early peripheralization of east central Europe also led to the formation of a few large urban centres. Gdansk most resembles the peripheral urban pattern described above. As we noted, it grew to a size of 50000 in 1600, larger than any other Polish town. In the process, it became something of a, 'materialist Mecca to which the Polish nobleman was drawn and tempted' (Davies, 1984: 272). This large Baltic port carried out functions analogous to other peripheral cities, as it was a key grain trans-shipment point and a centre for upper-class consumption. But it was not a site of political control over its hinterlands.

Other towns were centres of political control and eventually became quite large. But they were less like the dependent cities characteristic of other peripheral areas since their size and importance were less related to external factors. By 1795, Warsaw reached a size of 150000 (Davies, 1984: 315) comparable to contemporary Berlin and Copenhagen. Prague had about 75000 residents, and the three cities which later became Budapest had a population of 50000 at the beginning of the nineteenth century (Pounds, 1985: 176-78). These cities were larger than contemporary North American ones: the largest of those, New York, only had 40000 residents in 1776 (Light, 1983: 196). Of course, none of these cities was anywhere near the size of the core's, London or Paris, which in 1800 had 800000 and 670000 respectively (Mumford, 1961: 355).

East central European cities were larger than those in the colonies because they were more than recently established peripheral outposts for a core power. These cities were sites of longstanding independent political administration. Krakow was the major royal city of Poland from the middle of the eleventh century until Warsaw took on this role in the sixteenth. Buda, later joined with Pest to form Budapest, first became the capital of the Hungarian kingdom in the thirteenth century (Birnbaum, 1987). Prague was capital of the Great Moravian state of the early middle ages, and remained important in the Austrian Empire. Thus, peripheral urbanization in east central Europe must be analysed with reference to the fact that core powers were not trading with politically subordinate colonies, 
but with societies possessing historical legacies of political independence. Consequently, some east European cities grew because they were the loci of political/administrative functions in independent states. In general, between 1650 and 1800 , political centres increased in importance relative to trading centres in central and eastern Europe (Hohenberg and Lees, 1985: 167).

Later peripheral urbanization in the region was complicated further by the political power of the three great eastern and central European empires, the Russian, Prussian and Austrian. The significance of the empires for east central European city growth is more apparent as these cities begin to industrialize, but even in the late 1700 s imperial power shaped urban destinies in the Czech lands, Hungary and Poland.

Polish lands were partitioned at the end of the eighteenth century among the empires. Krakow went to Austria, although it remained a 'free city' under the empire's hegemony until 1846, when the revolution inspired more direct control (Davies, 1984: 335). Danzig came under Prussian rule, and its hinterlands were lost to the Russian empire, leading to the city's decline as a commercial centre (Pounds, 1979: 469). Warsaw came under Russian domination, and its population growth stagnated for the first two-thirds of the century (Pounds, 1979: 172-73), as the number of administrative positions in the state bureaucracy dropped significantly (Zarnowski, 1964: 77).

Vienna was the centre of the Austrian empire and guarded its central position. Vienna grew from 225000 in 1810 to 2080000 in 1910 (Pounds, 1985: 175). Through the mid-nineteenth century, the development of Prague, Budapest, and Krakow was limited by the restriction of their administrative function and the concentration of commercial activities in Vienna. The Austrian capital fulfilled the functions of administration and elite consumption provided by peripheral cities in the colonies.

After the 1867 Ausgleich, however, Budapest became a political equal to Vienna, and increased its own primacy within the empire considerably. In 1800 , Prague was one and one half times larger than Budapest. Even in 1850, after the construction of the first bridge linking Buda and Pest, these cities' combined population was only 150000 , with Prague not far behind at 118000 . But in the years following the Ausgleich, Budapest grew far more quickly than Prague. By 1870 , it had reached 300000 , in 1900,800000 , and by the beginning of the first world war, 1000000 . Prague's population also rose steadily, but not at quite so furious a pace: in 1870 it stood at 162 000, and in 1910, 225000 (Pounds, 1985: 174-75). Clearly, the geographical closeness of Vienna to the Hungarian and Czech peripheries discouraged the kinds of primate patterns normally associated with urbanization in peripheralized societies. However, this was not caused by periphery alone. The imperial state played a direct role in policies which amounted to implicit urban planning. Once Budapest acquired greater status and more political functions, its growth became more autonomous and less controlled by Vienna.

Empires were not only significant for their domestic effects, but also for their 
influence on the flow of international capital. Empires used political tools (tariff barriers, tax laws and state fiscal resources) to try and steer development in their own interests. To the degree they could pursue policies analogous to contemporary dependent development, some of the features of classical peripheral urbanization could be avoided.

Does all of this vitiate the usefulness of the concept of peripheral urbanization? We argue that it does not. Peripheralization occurs in different ways in different times and places: explanations of urbanization in specific places and times must take mitigating factors like geography or political arrangements into account. Eastern Europe's proximity to the metropoles of western Europe meant that 1) no single central trans-shipment points were needed to prepare bulk products for long transoceanic journeys, and thus several transportation nodes could compete within a small area; and 2) the agrarian elites had easier access to consumption in the major cities of the core of the world system or at least the centres of their empires. Politically, these peripheral areas were not colonies of the core, and were instead already urbanized independent agrarian societies, which allowed a greater role for the state in channelling urban development. Regardless of their commercial centrality, capital cities grew rapidly. Shifting political fortunes also led to changing boundaries which cut thriving ports from their hinterlands, and drastically altered the administrative functions of established capitals. This led to an urbanization pattern that was more discontinuous and more widely distributed among several cities. Some of the same political and economic pressures which led to primate colonial cities in America were thus associated with more even levels of urbanization in east central Europe.

Partly because of geographic and political factors, both peripheralization and city growth did not proceed along the same trajectory everywhere in east central Europe. There clearly were large pockets where the beginnings of urbanization and industrialization took root at relatively early points. In contrast to most regions in the overseas colonies, the economic peripheralization of eastern Europe sometimes protoindustrialization (Pfister, 1987) rather than monoproduction. Nascent nation states and empires had an interest and ability to shape urban patterns through economic policies designed to promote indigenous industrialization and development: colonized areas had no independent political apparatus to promote local economic growth and ended up playing an economically specialized role that fitted the needs of the core powers. Eastern European empires, particularly, had sufficient geopolitical clout to contend more effectively with core economic powers, promote domestically advantageous economic development, and, consequently, foster a more even pattern of urbanization. The influence of empires is especially evident in the development of the Czech lands.

By the mid-seventeenth century, English and Dutch traders were already establishing a linen trade with Bohemia (Stokes, 1987) and later Silesia (Pfister, 1987). Raw linens were produced by protoindustrial rural small-scale producers and exported to the west to be dyed and made into garments. This is not the same as the autonomous economic growth of western Europe, as this incipient 
industrialization was part of the peripheralization that produced the 'second serfdom' in east central Europe. An abundance of increasingly exploited peasant labour created an ideal situation for a rise in textile production which international traders could sell very cheaply on world markets. Despite increases in output, this production resulted in a, 'low dynamic of industrial accumulation and the absence of an industrial capitalist elite' in Silesia (Pfister 1987: 16). In Bohemia, however, political instruments channelled this growth in more generative directions. Under Maria Theresa, an aggressive mercantilist policy was established in the $1700 \mathrm{~s}$, attempting to restrict Bohemian trade within the Hapsburg Empire. This led local aristocrats to dye and manufacture the linens themselves. By 1789 , there were over 528000 persons engaged in textiles, and Brno, in Moravia, had become the 'Manchester of central Europe'. By 1880, a substantial amount of genuine industrialization had taken place in the Czech lands, especially in textiles, beets, coal and machinery (Stokes, 1987: 35-38). Czech lands were thus industrialized early, largely as a result of Austrian mercantilist policy.

The early start of manufacturing in Bohemia was important for urbanization patterns in the Czech lands. Much of this industrialization and protoindustrialization was dispersed, located close to the factors of production, facilitating more even urbanization.

The Hungarian territory under the Hapsburgs followed a different path. Protoindustrialization did not occur on a large scale here. Instead Hungary remained a major agrarian power in the fifteenth and sixteenth centuries, exporting livestock and copper, and importing quality textiles from western Europe. This export to the west, channelled through Vienna, continued even after Hungary's conquest by the Ottoman Turkish Empire and annexation by the Hapsburg Empire in the first third of the sixteenth century. Its export prospects were hurt more seriously by the growth of the Atlantic trade. Southern German towns declined as centres of transit for Hungarian goods, and Austria came to dominate the Hungarian territory more as it became the principal destination for Hungarian exports. Austria also restricted manufacturing in Hungary through differential tariffs, thereby reinforcing aristoctratic power and further underdeveloping Hungary. In fact, 'there seems to be a direct link between Austrian industrialization and the expansion of Hungarian cereal production' (Stokes, 1987: 42). As a consequence, there was little growth of medium-sized cities, and Budapest remained the administrative centre and towering primate city for the Hungarian territory through the first two-thirds of the nineteenth century.

But how do we assess the comparative primacy of Budapest? Primacy in the Austro-Hungarian empire is complicated by the difficulty of defining the boundaries of urban systems. Is the entire empire the relevant unit of analysis? Or just the official Hungarian territory? If the latter, our case is still complicated since Hungary was historically much larger than it is now: contemporary Bratislava in Slovakia was a first-order regional centre of the Hungarian lands, as was Zagreb in Yugoslavia and Cluj in Romania. Changing national borders 
have increased the relative priimacy of Budapest (see Enyedi, 1976: 20-21).

Changing political boundaries are even more critical when considering the Polish case. Once a great kingdom like Hungary, Poland was partitioned at the end of the eighteenth century by the Russian, Prussian and Austrian empires. But Poland's partition carried different consequences from Hungary's domination by the Hapsburgs.

\section{VII 'Dependent development' in the empires and new nations}

Although some protoindustrialization began early, it was not until the late 1800 s that large-scale manufacturing began to make a significant impact in most of eastern Europe. Even then, this industrialization was an uneven process which had more in common with the development of manufacturing in the newly industrializing countries of the twentieth century than autonomous capitalist development in the core nations during the industrial revolution. It was heavily financed by foreign capital, proceeded at differential rates in various locales, and took place under the aegis of state intervention in both empires and independent nations.

Industrialization took different forms depending on the empire and territory in that empire we consider. The Hapsburg monarch encouraged industrialization early on in the Czech lands, ultimately contributing to a more even urbanization there. Major manufacturing began to develop in the early 1800 s (Berend and Ranki, 1974: 123).

The Austrian authorities discouraged industrial investment in Hungary, until after the 1873 financial crash when a series of Austrian capitalists invested substantially in flour production, on the raw cereals Hungary herself produced. In the second half of the nineteenth century, foreign investment was $40 \%$ of all investments in Hungary (Berend and Ranki, 1982: 87). Much of this industrialization took place in Budapest itself, reinforcing the primacy that city enjoyed as an administrative centre (Stokes, 1987: 46; Enyedi, 1976: 16-17).

Rather than being underdeveloped by the centre, as Vienna did to Hungary before the 1873 financial crash and the 1867 compromise, the Polish territory incorporated into the Russian empire developed relatively quickly. In fact, the Polish territories industrialized and urbanized more rapidly than any other part of the Empire in 1885-97 (Fedor, 1975: 127). The Russian Empire was a huge market for Polish industry, and foreign investors took note. Foreign capital accounted for approximately $60 \%$ of industrial production in Russian Poland (Davies, 1984: 163-77). In fact, after the Russian Empire established a protective tariff against foreign goods in 1880, foreign (especially German) capital cooperated with the Congress Kingdom government to build up Poland's 'Manchester', Lodz, to manufacture textiles for the Russian and expanding Polish markets. In 1850 , Lodz had about 16000 residents, but by 1900 there were 321000 , and by 1913 over 500000 (Pounds, 1985: 409-10; Turnock, 1978: 176-78). 
The industrialization of east central Europe, especially of Hungary and Poland, depended heavily on foreign capital. But this dependency was not similar to the kind of dependency peripheral nations usually suffer. In much of eastern Europe, excluding the Balkans (Berend and Ranki, 1974:111), the state had considerable power to counter the interests of the foreign (especially Austrian, German, and French) capitalists, and thus minimize the 'distortion' of development by foreign interests (Berend and Ranki, 1982: 81). Much of the capital which entered eastern Europe entered through the local government or its own leading financial groups, so that investment led to indigenous development and capital accumulation. Foreign capital was used to construct an extensive infrastructure, especially in railroads, which would sustain domestic development (Berend and Ranki, 1982: 87).

Both the move toward state-centric development and its diversified production mix suggests that east central Europe under the empires was moving from the periphery into the semi-periphery of the world economy. A process analogous to the dependent development of the contemporary semi-periphery was underway in this part of Europe 75 years ago. But the first world war changed these industrial and urban prospects.

War damage was considerable. The Russian revolution cut off a huge market for newly independent Poland. Poland was forced to integrate territories linked to different empires. The central powers were defeated, and Austria and Hungary were reduced to fractions of their former size and influence. The Czech lands were united with Slovakia, an agricultural area formerly part of Hungarian territory. Czech development was greatest of the territories under consideration, and promoted a rather even urbanization throughout the Czech lands.

Although there was industrial development in this region between the wars, world economic and political problems posed serious difficulties. East central Europe made gains prior to the first world war, but its economic development fell even further behind the west in the 1920s (Berend and Ranki, 1974: 241). In Hungary, foreign investment declined dramatically, and trade dropped off with the former members of the Austro-Hungarian Empire. Hungary became more economically integrated with Germany (Enyedi, 1976: 20). Poland's growth was also limited for various reasons, but it did manage to integrate the country economically, develop Gdynia as a Polish alternative to the port of the free city Danzig, and build a large industrial sector in the middle of the country (Dziewonski and Jerczynski, 1975: 267-68). Still, it was not until the last years of the 1930s that there was substantial economic recovery (Davies, 1984: 418).

Whether any eastern European country could have recovered enough to enter the core of the world capitalist system becomes a moot question with the outbreak of the second world war. The war destroyed many of the accomplishments of eastern European industrialization and urbanization. Over $38 \%$ of Poland's total wealth was destroyed, and over six million Poles were killed (Jakowicz, 1979: 14). Hungarian losses were behind only Poland and Yugoslavia; over 600000 Hungarians were killed and war damages were more than twice the GNP of the 
year preceding the war (Enyedi, 1976: 20). Again, Czechoslovakia suffered less and had a better base for development in the postwar world. But in the aftermath of the war, the entire region was forced to recover from the ashes of ruined semiperipheral industrializing capitalist societies.

\section{Semi-peripheral urbanization}

Is there a semi-peripheral pattern of urbanization? Some aspects of dependent urbanization's unevenness may be mitigated in upwardly mobile capitalist semiperipheral societies when their economies rely on export-oriented manufacturing. This lessens the advantages of a large concentrated market of high-income consumers, one factor encouraging primate cities in the periphery (Nemeth and Smith, 1985; Roberts, 1978). Strong developmentalist-minded states also have the will and capacity to fomulate and implement policies which promote more balanced urban systems.

Although east central Europe historically had more evenly developed urban systems upon which to build than most colonial societies, east central European industrialization between 1860 and 1940 appears to have had some effects similar to those occurring in other semi-peripheral cases. Cities, even in the region's most industrial areas, grew more slowly than those in western Europe during this period. City growth also seems to have been more widely spread on small and medium-sized places (Dziewonski and Jercznski, 1975; Musil and Rysavy, 1983). Why was this?

As in the contemporary semi-periphery, one answer lies in the type of industrialization. Manufacturing was more capital-intensive, needing less labour. It was also oriented toward development of the means of production, not consumption. The market concentration created by very large, inegalitarian cities was not important for this industrialization path. A more spatially dispersed production-oriented urban system could develop throughout eastern Europe instead (Musil, 1980). In the Czech territory, early industrial development stimulated the growth of small cities located near the factors of production (Musil and Rysavy, 1983: 504). Spatially, even urban growth in Poland in the early twentieth century was facilitated by the development of integrated transportation and communications networks (Dziewonski and Jerczynski, 1975: 267-68).

There are two other factors which do not mirror conditions in the third-world semi-periphery today, however. First, substantial numbers of Poles, Hungarians, and other east Europeans (less so Russians) emigrated at the end of the nineteenth and beginning of the twentieth century. Emigration absorbed between one-fifth and one-quarter of Hungarian population growth between the 1870s and the first world war, with about two million Hungarians leaving. Even more Poles emigrated, with an estimated number of 3.5 million (Berend and Ranki, 1974: 20). Secondly, early industrialization in eastern Europe was accompanied by the retention of a more labour-intensive agriculture. Rather than mechanizing 
agriculture, estates relied on the cheap labour available in the countryside. There was very high agricultural density and high rural unemployment rates, even through the interwar period (Berend and Ranki, 1974: 294-96). Thus, there was less cityward migration and more international outmigration in the prerevolutionary eastern European semi-periphery than there is in the contemporary semiperiphery.

\section{Urban policy under 'actually existing socialism'}

After the second world war, communist regimes came to power throughout eastern Europe. The state in these actually existing socialist societies has overseen a planned and controlled process which Musil (1980: 6) calls 'managed urbanization'. The formulation of urban planning strategies has stressed both productive efficiency and the 'intensification' of the economy, with a subsidiary emphasis on minimizing material and geographical inequalities. Musil (1980) provides an overview of these policies and their evolution in particular countries. These policies sought to avoid the diseconomies of very large cities, provide the social advantages of more spatially dispersed development and to pursue strategies that, at least, lead to 'polycentric concentration' (p.11).

Generally the resulting patterns of urbanization reflect the attempt to stimulate growth in small and medium cities and also reduce inequalities. Polish urban policies, for instance, have suceeded in '. . . limiting the growth of the largest cities (though not of the fringe areas) and in supporting development of mediumsized ones' (Dziewonski and Jercznski, 1975). Similarly, Czech industrial recovery strategies in the 1950 s were designed to exploit existing factories and other infrastructure which was already distributed widely in small and mediumsized towns (Musil and Rysavy, 1983: 522). This led to the rapid growth of 'smaller towns, some medium sized towns and Ostrava as the only large city' (Musil and Rysavy, 1983: 507). Even in Hungary, where Budapest continues to tower over the rest of the urban hierarchy, comprehensive national urban policies have been developed to combat the capital's 'excessive concentration' of population, resources and economic, administrative and service functions (Musil, 1980). Paul Beluszky (1978) documents how the urban hierarchy, while remaining largely the same, has decreased the importance of regional centres in favour of country seats, and decreased the significance of medium-sized cities in favour of district seats. What is more, the regional centres are growing more quickly than Budapest (Enyedi, 1976: 160). There are moves toward greater regional equality, but differences remain (Enyedi, 1976: 117-18).

Socialist urbanization in east central Europe reflects the planned restriction of the development of larger cities and the encouragement of smaller places, an overall move toward greater regional equality and little 'suburbanization' in the core capitalist sense but considerable commuting to workplaces. Even though urban life continues to receive disproportionate shares of national resources, state 
policies throughout east central Europe have also been designed ostensibly to promote more equitable (if not always adequate) distribution of urban amenities, addressing another facet of what we refer to as uneven urbanization.

Not surprisingly, there are considerable similarities in urbanization between east central Europe and the PRC, given their common political economies and similar urban policies (Whyte and Parish, 1984). But these policies of 'managed urbanization' are also similar to policies in the capitalist third world designed to promote decentralization and greater intraurban equality (Lo and Salih, 1978; Mills and Song, 1979; Renaud, 1981). Might the similar policies of different political economies be attributable to common problems and resources given semi-peripheral regions in the capitalist world system?

\section{Conclusions}

In what way does a region's role in the modern world-system inform our understanding of east central European urbanization? First, contemporary urbanization patterns are built on patterns established in the historical development of these areas. Urbanization and development in eastern Europe up until the 1800 s (or even later) reflected the peripheralization of the region in the 'long sixteenth century', although the classic patterns of peripheral urbanization were mitigated by geographic and political factors.

Secondly, city growth is affected by recent and contemporary roles played by regions in the international system. From protoindustrialization to the present, east central Europe has shown signs of reaching the semi-periphery, through the imperial practice of using state apparatuses to shape foreign investment to domestic advantage. The Balkans resemble more the peripheral pattern, but the urbanization of the Czech lands, Poland, and Hungary in the 70 years before the second world war is characteristic of their status as upwardly mobile semiperipheral societies.

East central European urbanization after the second world war fits the semiperipheral mold even more closely. We have claimed that pattern bears strong similarities both to societies with a common political economy, like the PRC, and to the capitalist semi-periphery, including the newly industrializing east Asian nations. Both east central Europe and east Asia had developed urban systems predating world capitalist penetration, have experienced dependent development, and today play similar roles in the world-system. In both of these capitalist and noncapitalist semi-peripheries, there have been substantial loans made by the core, and substantial debts remain. In both semi-peripheries, exports are made more competitive by exploiting 'cheap labour': peasant-workers in eastern Europe occupy a kind of semi-proletarian status, providing much of their own food and thereby decreasing actual labour costs (Szelenyi, 1981; Wallerstein, 1984). In both semi-peripheries, development is led by a strong 'state', which uses political repression to impose austerity while facilitating development. 
Of course, there are a number of differences between these regions as well. One important divergence for the world system approach may be these region's future trajectories. It appears that without substantial social transformation in eastern Europe, western capital investments and successful exports have passed their peak. The Asian rim, on the other hand, seems to occupy a fortuitous place for 'upward mobility' in the international system. ${ }^{7}$ We might therefore expect east European semi-peripheral urban patterns increasingly to resemble city configurations in other cases where societies are in decline. Instead of talking about some generic form of semi-pheripheral urbanization, it is more useful to see the process as one connected to upward or downward mobility in the world economy (Smith and Nemeth, forthcoming).

Speaking of trajectories raises the connection between the past and present. Some have noted that semi-peripheral status in the contemporary world system is correlated highly with an agrarian technoeconomic heritage and geographically advantageous accidents (Lenski and Nolan, 1984). Fairly arbitrary national boundaries which assigned large reserves of oil to Nigeria and a huge resource base and population to Brazil have promoted dependent development in both countries; the Korean peninsula's isolation from major world trade routes helped protect that society from early peripheralization.

A major issue confronting world-system approaches is accounting for technoeconomic heritage and other historical legacies in explanation. One reason for the more even urbanization patterns of east central Europe, the PRC and South Korea is their commonly advanced agrarian background. Socialist urbanization in east central Europe and the PRC and semi-peripheral South Korean urban development are building on comparative regional equality that existed before revolution and world system incorporation. Macrostructural phenomena like urbanization patterns have a significant degree of institutional momentum. World-system 'status' at any given point in time can only shape what has come before. Likewise socialist transformation. A holistic international political economy approach cannot just search for the variable that explains the most variance in urban outcomes. It must seek to understand how different combinations of circumstances lead to various types of historical change.

Consequently, it becomes important to select cases carefully for comparison. To address the distinctiveness of socialist urbanization as opposed to capitalist, one presumably ought to compare East and West Germany, North and South Korea, or even Bulgaria and Greece. To address the significance of semiperipheral versus peripheral status before socialist transformation, one ought to compare the PRC or the Balkans with east central Europe. But before such contrasts are made, one must define 'socialist' and 'semi-peripheral' urbanization in theoretical terms that are appropriate to these various regional experiences. We have sought to contribute to this conceptual development by rethinking the meaning of these ideas for interpreting east central European urbanization.

${ }^{7}$ Although this is not guaranteed. See Cumings, 1984 for a discussion of 'Korea's export-led trap'. 
Use of this approach to explain this region's urbanization leads to several problems. One of the most prominent that we have encountered is the demarcation of urban systems for definitions of urban primacy. What were the meaningful boundaries at the end of the nineteenth century and beginning of the twentieth? Were they empire boundaries or national ones? How then do we compute primacy ratios? (see Walters, 1985).

The problem reappears in modified form when it comes to identifing societies in space over time. Hungary lost significant cities and capital investments as a consequence of being on the wrong side in the first world war. Poland gained an important industrial urbanized area after the second world war when its borders were moved 150 miles west. When boundaries change, so do urban systems and their comparability in history. Do we leave these issues as caveats, or can they be incorporated into a more systematic perspective on urbanization? The only way to incorporate these historical particulars theoretically is by using them as data with which we reformulate concepts themselves.

The world-system perspective has introduced an important interpretive schema to the comparative historical analysis of cities, but conceptual development of peripheral and semi-peripheral urbanization has focused almost exclusively on third-world regions that are former core colonial dependencies. Eastern Europe offers a valuable opportunity to 'deepen the analogy' (Stinchcombe, 1979) of 'dependent urbanization' by recasting general notions of peripheral and semiperipheral urbanization.

The region's geographic proximity to the core and the power of the independent kingdoms and empires of east central Europe altered the urban outcomes of peripheralization, and later facilitated the process of dependent development. Wars and the redrawing of political boundaries led to different effects, leaving Hungary more primate and Poland more urban than otherwise. The initial years of socialist transformation had a more consistent impact throughout the region, as the state utilized central planning to augment the decentralization characteristic of upwardly mobile semi-peripheral urbanization. It is unclear, however, whether Soviet-type economies are so upwardly mobile today.

Bringing the state into the centre of the world-system perspective has improved our ability to explain semi-peripheral urbanization in eastern Europe. Simultaneously, examining eastern Europe through a world system lens sharpens our image of variations in urban pattern and process in the semi-periphery. Cities and urban systems in contemporary east central Europe can be partially understood as products of industrialization and socialist political economy. But our research demonstrates that an international political economy approach, placing this urbanization in the context of dependent development in the semi-periphery of the capitalist world-system, provides an analytically powerful framework too. 


\section{References}

Anderson, P. 1974: Lineages of the absolutist state. London: Verso.

Andrusz, G. 1984: Housing and urban development in the USSR. Albany: State University of New York Press.

Arato, A. 1985: Between reductionism and relativism: Soviet society as a world system. Telos $63,178-87$.

Arrighi, G. and Drangel, J. 1986: The stratification of the world-economy: a preliminary exploration of the semiperpheral zone. Review 10, 9-74.

Berend, I. T. and Ranki, G. 1974: Economic development in east central Europe in the 19th and 20th centuries. New York: Columbia University Press.

1982: The European periphery and industrialization: 1780-1914. New York: Cambridge University Press.

Beluszky, P. 1978: Changes in urban hierarchy with specific respect to urbanizing regions in Hungary. In Enydei, G., editor, Urban development in the USA and Hungary, Budapest: Akademiai Kiado.

Bialecki, I. and Sikorska, J. 1982: Podstawowe potrzeby i aspiracje zyciowe Polakow w sytuacji kryzysu. In Adamski, W. et al., Polacy 81, Warsaw: PAN IFIS, 13-46.

Birnbaum, M. D. 1987: Buda between Tartars and Turks. In Krekic, B., editor, Urban society of eastern Europe in premodern times, Berkeley: University of California Press, $137-57$.

Bradshaw, Y. 1985: Overurbanization and underdevelopment in sub-Saharan Africa: a cross-national study. Studies in Comparative International Development 20, 74 101.

Castells, M. 1977: The urban question: a Marxist approach. Cambridge, MA: MIT Press.

Caparaso, J. 1981: Industrialization at the periphery: the evolving global division of labor. International Studies Quarterly 25, 347-84.

Chase-Dunn, C., editor, 1982: Socialist states in the world-system. Beverly Hills: Sage, 1984: Urbanization in the world-system: new directions for research. In Smith, $\mathbf{M}$. P., editor, Cities in transformation, Beverly Hills: Sage Publications, 111-200. 1988: Global formation: structures of the world-economy. New York: Basil Blackwell.

Chase-Dunn, C. and Rubinson, R. 1977: Toward a structural perspective on the world system. Politics and Society 7, 453-76.

Chirot, D. 1986: Social change in the modern era. San Diego: Harcourt Brace Jovanovich.

Clark, C. and Bahry, D. 1983: Dependent development: a socialist variant. International Studies Quarterly 27, 271-93.

Cohen, M. 1974: Urban policy and political conflict in Africa: a study of the Ivory Coast. Chicago: University of Chicago Press.

Cumings, B. 1984: The origins and development of the northeast Asian political economy: industrial sectors, product cycles, and political consequences. International Organization 38, 1-40.

Davies, N. 1984: God's playground: a history of Poland. New York: Columbia University Press.

Demko, G. and Fuchs, R. 1977: Commuting in the USSR and eastern Europe: causes, characteristics and consequences. East European Quarterly 9, 463-75. 
Denemark, R. and Thomas, K. 1988: The Brenner-Wallerstein debate. International Studies Quarterly 32, 47-65.

Diehl, J. 1986: Poorest Poles fall below the reach of state's welfare. The Washington Post, 24 January.

Dziewonski, K. and Jerczynski, M. 1975: Poland. In Jones, R., editor, Essays on world urbanization, London: George Philip and Sons.

Enyedi, G. 1976: Hungary an economic geography. Builder: Westview.

Evans, P. 1979a: Beyond center and periphery: a comment on the world system approach to the study of development. Sociological Inquiry 49, 15-20.

1979b. Dependent development. Princeton, NJ: Princeton University Press.

Evans, P. and Stephens, J. 1988: Studying development since the sixties: the emergence of a new comparative political economy. In Smelser, N., editor, The handbook of sociology, Beverly Hills, CA: Sage.

Feagin, J. and Smith, M. 1987: The capitalist city. New York: Basil Blackwell.

Fedor, T. S. 1975: Patterns of urban growth in the Russian Empire during the nineteenth century. University of Chicago, Department of Geography, Research Paper, No. 163.

Fiala, R. and Kamens, D. 1986: Urban growth and the world polity in the nineteenth and twentieth century. Studies in Comparative International Development 21, 2335.

Frank, A. G. 1969: Latin America: underdevelopment or revolution? New York: Monthly Review.

1977: Long live transideological enterprise! The socialist economies in the capitalist international division of labor. Review 1, 91-140.

Friedmann, J. and Wolf, G. World city formation: an agenda for research and action. International Journal of Urban and Regional Research 6, 309-44.

Gugler, J. and Flanagan, W. 1977: On the political economy of urbanization in the third world: the case of West Africa. Intenational Journal of Urban and Regional Research 1, 272-92.

Hohenberg, P. and Lees, L. H. 1985: The making of urban Europe 1000-1950. Cambridge: Harvard University Press.

Holton, R. J. 1986: Cities, capitalism and civilisation. London: Allen and Unwin.

Jakowicz, J. 1979: Poland's postwar recovery. Hicksville, NY: Exposition University Press.

Jalowiecki, B. 1982: Strategia uprzemysolwienia a proces urbanizarja. Warsaw: XXX.

Kentor, J. 1981: Structural determinants of peripheral urbanization: the effects of international dependence. American Sociological Review 46, 201-11.

Konrad, G. and Szeleny, I. 1977: Social conflicts of underurbanization. In Harloe, M., editor, Captive cities, London: Wiley, 157-74.

Kornai, J. 1980: Economics of shortage. Amsterdam: XXX.

Kovrig, B. 1900: Hungary. In Teresa Rakowska-Harmstone, T., editor, Communism in eastern Europe, Bloomington: Indiana University Press, 85-115.

Lenin, V. I. 1956: The development of capitalism in Russia. Moscow: Foreign Language Publishing House. (First published in 1907.)

Lenski, G. and Lenski, J. 1987: Human Societies. New York: McGraw Hill.

Lenski, G. and Nolan, P. 1984: Trajectories of development: a test of ecological evolutionary theory. Social Forces 63, 1-23.

Light, 1. 1983: Cities in world perspective. New York: MacMillan. 
Lo, F. C. and Salih, K. 1978: Growth pole strategy and regional development. New York: Pergamon Press.

London, B. 1979: Internal colonialism in Thailand: primate city parasitism reconsidered. Urban Affairs Quarterly 14, 485-517.

London, B. and Smith, D. A. 1987: Urban bias, dependence, and economic stagnation in non-core nations. American Sociological Review 53, 454-63.

Luke, T. 1984: Review symposium on Soviet-type societies. Telos 60, 155-61. 1984-85: On the nature of Soviet society. Telos 63, 187-95.

Meyer, D. 1986: The world system of cities: relations between international financial metropolises and South American cities. Social Forces 64, 553-81.

Mills, E. and Song, B. N. 1979: Studies in the modernization of the Republic of Korea, 1945-1975: urbanization and urban problems. Cambridge, MA: Harvard University Press.

Misztal, B. and Misztal, B. 1984: Urban social problems in Poland: the macrosocial determinants. Urban Affairs Quarterly 19, 315-28.

Mumford, L. 1961: The city in history. New York: Harcourt Brace and World.

Murray, P. and Szelenyi, I. 1984: The City in the Transition to Socialism. International Journal of Urban and Regional Research 8(1) 90-108.

Musil, J. 1980: Urbanization in socialist countries. White Plains, NY: M E Sharpe.

Musil, J. and Rysavy, Z. 1983: Urban and regional processes under capitalism and socialism: a case study from Czechoslovakia. International Journal of Urban and Regional Research 7, 495-527.

Nemeth, R. and Smith, D. A. 1985a: The political economy of contrasting urban hierarchies in South Korea and the Philippines. In Timberlake, M., editor, Urbanization in the world-economy, New York: Academic Press.

1985b: International trade and world-system structure: a multiple network analysis. Review 8, 517-60.

Ostrowski, K. and Valkonen, T. 1978: Regional development. In Allardt, E. and Wesolowski, W., editors, Social structure and change: Finland and Poland: comparative perspective, Warsaw: Polish Scientific Publishers.

Pfister, U. 1987: Systems differentiation within the world-system: protoindustrialization as a mode of production within the early modern international political economy. Paper presented at the annual meetings of the International Studies Association, Washington, DC.

Pounds, N. 1979: An historical geography of Europe: 1500-1840. Cambridge, UK: Cambridge University Press.

1985: An historical geography of Europe 1800-1914. Cambridge, UK: Cambridge University Press.

Renaud, B. 1981: National urbanization in developing countries. Baltimore: The Johns Hopkins University Press.

Rev, I. 1984: Local autonomy or centralism: when was the original sin committed? International Journal of Urban and Regional Research, 8, 38-63.

Roberts, B. 1978: Cities of peasants. Beverly Hills: Sage.

Rocznik Statystyczny 1983: Warsaw: Glowny Urzad Statystyczny.

Saueressig-Schreuder, Y. 1986: The impact of British colonial rule on the urban hierarchy of Burma. Review 10, 245-77.

Slater, D. 1978: Toward a political economy of urbanization in peripheral capitalist societies. International Journal of Urban and Regional Research 2, 26-52. 
Smith, D. A. 1985: International dependence and urbanization in east Asia: implications for planning. Population Research and Policy Review 4, 203-33.

1987: Dependent urbanization in colonial America: the case of Charleston, South Carolina. Social Forces 66, 1-28.

Smith, D. and White, D. 1988: Structure and dynamics of the global economy: network analysis of international trade, 1965-1980. Paper presented at the annual meeting of the American Sociological Association, August, Atlanta, GA.

Smith, D. A. and Nemeth, R. J. forthcoming: Dependent urbanization in the contemporary semiperiphery? Deepening the analogy. In Drakakis-Smith, D., editor, The urban totem: economic development and urbanization in the periphery and semi-periphery, London: Croon Helm.

Snyder, D. and Kick, E. 1979: Structural position in the world system and economic growth: a multiple network analysis of transnational interactions. American Journal of Sociology 84, 1096-126.

Stinchcombe, A. 1979: Theoretical methods in social history. New York: The Free Press.

Stokes, G. 1987: The social origins of east European politics. East European Politics and Societies 1, 30-74.

Szelenyi, I. 1977: Urban sociology in eastern Europe. Comparative Urban Research $4(2,3)$ 39-60.

1981. Urban development and regional management in eastern Europe. Theory and Society 10, 169-205.

1983: Urban inequalities under state socialism. Oxford: Oxford University Press.

Timberlake, M., editor, 1985: Urbanization in the world-economy. New York: Academic Press.

Timberlake, M. and Kentor, J. 1983: Economic dependence, overurbanization, and economic growth: a study of less developed countries. Sociological Quarterly 24, 489-507.

Turnock, D. 1978: Eastern Europe. Boulder, CO: Westview.

United Nations, 1980: Patterns of urban and rural development growth. St/ESA/ SER.A/69. New York: United Nations.

Wallerstein, I. 1974: The modern world-system I. New York: Academic Press.

1984: Cities in socialist theory and capitalist praxis. International Journal of Urban and Regional Research 8, 64-72.

1985: The relevance of the concept of semiperiphery to southern Europe. In Arrighi, G., editor, Semiperipheral development, Beverly Hills, CA:Sage, 31-54.

Walters, P. 1985: Systems of cities and urban primacy: problems of definition and measurement. In Timberlake, M., editor, Urbanization in the world-economy, New York: Academic Press, 63-85.

Walton, J. 1977: Accumulation and comparative urban systems: theory and some tentative contrasts of Latin America and Africa. Comparative Urban Research 5 , 5-18.

1979: Urban political economy: a new paradigm. Comparative Urban Research 7 , 5-17.

1981: The new urban sociology. International Social Science Journal 33, 374-90.

1982: The international economy and peripheral urbanization. In Fainstein, N. and Fainstein, S., editors, Urban policy under capitalism, Beverly Hills: Sage Publications, 119-35. 
Weglenski, J. 1983: Urbanizacja: kontrowercje wokol pojecia Warsaw: Panstwowe Wydawnictwo Naukowe.

Whyte, M. K. and Parish, W. L. 1984: Urban life in contemporary China. Chicago: University of Chicago Press.

Zarnowski, J. 1964: Struktura spoleczna inteligencji w Polsce w latach 1918-1939. Warsaw: Panstwowe Wydawnictwo Naukowe.

Zaslavsky, V. 1984-85: Soviet society and the world systems analysis. Telos 62, 15568.

1985: The Soviet world system: origins, evolution and prospects for reform. Telos $65,3-22$.

In the 1980 s global political economy approaches have dominated comparative research on urbanization and development. Most of the literature focuses on rapid peripheral urbanization in the third world or the growth of 'world cities' in the core nations. These approaches have paid relatively little attention to urbanization in the 'actually existing socialist societies'. Urbanization in east central Europe (Poland, Hungary, the Czech lands) is examined in light of the political economy of the world-system perspective. The periperalization of east central Europe in 'the long sixteenth century' was complicated by the region's proximity to the core and by the power of independent states. Beginning in the eighteenth century empires in this region limited the economic penetration by the core and facilitated dependent development in some parts of the area. Current patterns of 'underurbanization', modest regional inequality, and low urban primacy rest on this historical foundation. Policies of 'managed urbanization' in postrevolutionary societies reinforce the semi-peripheral legacy of decentralized, relatively even city growth. Illustrating the advantages of this perspective, urban similarities are noted not only to socialist countries, but also to those in the capitalist semi-periphery. The key role of the state in reshaping dependent urbanization and development, highlights the importance of 'bringing the state back in' to research on global political economy.

Pendant les années 1980, les théories en économie politique générale ont dominé les recherches comparatives sur l'urbanisation et l'urbanisme. La plus grande partie de la littérature centre sur l'urbanisation périphérique rapide dans le tiers-monde ou sur la croissance des mégalopoles dans les pays clé. Ces théories ont à peine considéré l'urbanisation dans les états socialistes actuels. L'urbanisation dans l'Europe centrale de l'Est (Pologne, Hongrie, territoires tchèques) est étudiée dans le cadre de l'économie politique du macrosystème. L'organisation des zones périphériques en Europe centrale de l'Est au cours du 'long seizième siècle' a été compliquée par la proximité de la région au noyau et par la puissance des états indépendants. Dès le début du dix-huitième siècle, les empires de cette région restreignaient la pénétration économique par le noyau et facilitaient le développement dépendant dans certaines parties du territoire. Les formes actuelles de sous-urbanisation, d'inégalité régionale modérée et de faible primauté urbaine reposent sur cette base historique. Les politiques d'urbanisation contrôlée dans les sociétés post-révolutionnaires étayent l'héritage d'une organisation semi-périphérique dans un développement urbain décentralisé et relativement homogène. Démontrant les avantages de cette perspective, les ressemblances urbaines se distinguent non seulement dans les pays socialistes mais aussi dans les régions semi-périphériques des pays capitalistes. Le rôle clé de l'État à remodeler l'urbanisation et le développement dépendants met en lumière l'importance de le ramener à la recherche sur l'économie politique globale.

Vergleichsstudien in den 1980er Jahren über Urbanisierung und wirtschaftliche Entwicklung sind in den Augen der Autoren relativ einseitig, da sie im wesentlichen nur von Ansätzen einer globalen Volkswirtschaft ausgehen. Der gröBte Teil der Literatur konzentriert sich auf die schnell fortschreitende Urbanisierung der Peripherie in den Ländern der Dritten Welt oder das Wachstum von 'Weltstädten' in den Kernstaaten. Diese Ansätze lassen jedoch die Urbanisierung in 'tatsächlich existierenden sozialistischen Ländern' weitgehend außer acht. Der UrbanisierungsprozeB im östlichen Mitteleuropa (Polen, Ungarn, Tschechoslowakei) wird in Zusammenhang mit einer vom Weltsystem abhängigen Volkswirtschaft betrachtet. Die Verdrängung des 
östlichen Mitteleuropas an die Peripherie während des 'langen' sechzehnten Jahrhunderts wurde sowohl durch seine geographische Nähe zum Kern als auch die Machteinflüsse unabhängiger Staaten erschwert. Zu Beginn des achtzehnten Jahrhunderts wurde der wirtschaftlichen Durchdringung seitens des Kerns Einhalt geboten und eine unabhängige Entwicklung in einigen Teilen gefördert. Die gegenwärtige 'Unterurbanisierung', ein geringes regionales Ungleichgewicht und eine schwache Dominanz der Städten sind auf diese historische Entwicklung zurückzuführen. Politische Maßnahmen einer 'gelenkten' Urbanisierung in postrevolutionären Ländern verstärtken die historische Tendenz zu einem dezentralen, relativ gleichmäßigen Städtewachstum. Der Autor nennt die Vorteile einer solchen Entwicklung und stellt nicht nur Ähnlichkeiten von Städten in sozialistischen Ländern, sondern auch in der kapitalistischen Semiperipherie fest. Die Schlüsselrolle des Staates bei der Urbanisierung und Förderung der wirtschaftlichen Entwicklung macht deutlich, wie wichtig es ist, den Staat in globale volkswirtschaftliche Untersuchungen mit einzubeziehen.

En la década de los 80 , los planteamientos de la economía política global han dominado la investigación comparativa de la urbanización y desarrollo. Gran parte de los textos especializados se centran en la rápida urbanización periférica del Tercer Mundo o en el crecimiento de las "ciudades mundo" de las naciones importantes. Estos planteamientos han prestado relativamente poca atención a la urbanización de las 'sociedades socialistas realmente existentes'. La urbanización en la Europa Centro-Oriental (Polonia, Hungría, Checoslovaquia) es examinada bajo el tinte de la economía política de la perspectiva del sistema mundial. La periferalización de la Europa Centro-Oriental del 'largo siglo dieciseis' se complicó debido a la proximidad de la región al centro y al poder de los estados independientes. A partir del siglo dieciocho, los imperios existentes en esta región limitaron la penetración económica por parte del centro y facilitaron el desarrollo dependiente en algunas partes de la zona. Los modelos actuales de 'infraurbanización', la desigualdad de las regiones modestas, y la poca primacía de los centros urbanos descansan en sus fundamentos históricos. Las políticas de 'urbanización controlada' de las sociedades postindustriales refuerza la herencia semiperiférica del crecimiento descentralizado y relativamente ecuánime de las ciudades. Ilustrando las ventajas de esta perspectiva, las similitudes urbanas son perceptibles no sólo en países socialistas, sino también en la semiperiferia capitalista. El papel clave del estado en la reforma de la urbanización y desarrollo dependientes resalta la importancia de "volver a atraer al estado" hacia la investigación relacionada con la economía política global. 